\title{
Acute Monoblastic Leukemia Presenting with Multiple Granulocytic Sarcoma Nodules
}

\author{
Granülositik Sarkom Nodülleri ile Ortaya Çıkan Bir Akut Monoblastik Lösemi Olgusu
}

Asude Kara1, Aslı Akın Belli1, Yelda Dere², Volkan Karakuş3, Şükrü Kasap4, Erdal Kurtoğlu5, Mine Hekimgi|6

${ }_{1}^{1}$ Muğla Sıtkı Koçman University Training and Research Hospital, Department of Dermatology, Muğla, Turkey

2 Muğla Sıtkı Koçman University Faculty of Medicine, Department of Pathology, Muğla, Turkey

${ }_{3}^{3}$ Muğla Sıtkı Koçman University Training and Research Hospital, Department of Hematology, Muğla, Turkey

${ }^{4}$ Muğla Sıtkı Koçman University Faculty of Medicine, Department of Plastic Surgery, Muğla, Turkey

${ }^{5}$ Antalya Training and Research Hospital, Clinic of Hematology, Antalya, Turkey

${ }^{6}$ Ege University Faculty of Medicine, Department of Pathology, Izmir, Turkey

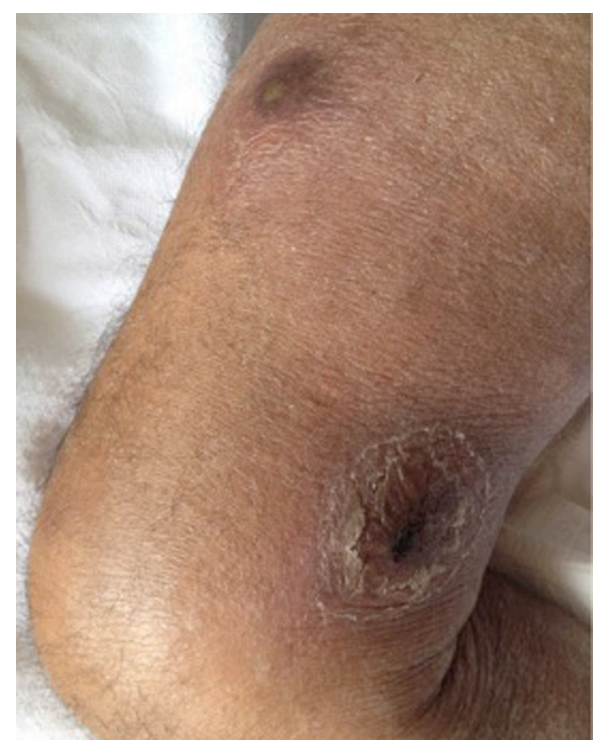

Figure 1. Violaceous nodules with central pustules and scaling on the right leg.

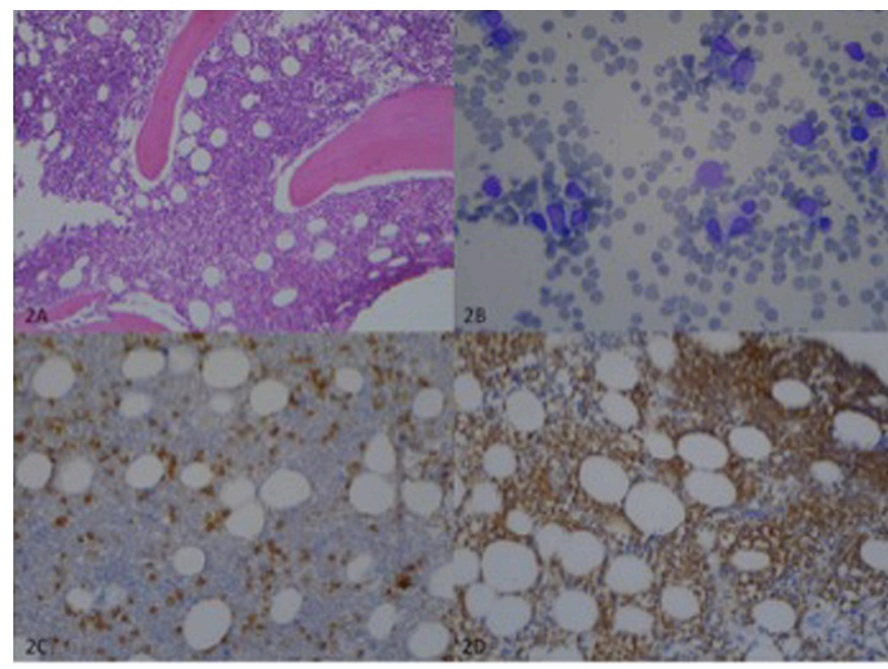

Figure 2. (A) Bone marrow biopsy showing hypercellularity ( $\mathrm{H} \& \mathrm{E}_{\text {, }}$ 100x). (B) Bone marrow aspiration smear showing erythroblasts and blastic cells with nuclear indentation (Giemsa, 400x). (C) CD34 (+) blastic cells (200x). (D) Myeloperoxidase (+) blastic cells (200x).
A 76-year-old male presented to the department of plastic surgery with multiple nodules on his legs for 1 month. On examination, there were five discrete, violaceous nodules with a size of $0.5-3 \mathrm{~cm}$ on the legs (Figure 1). Laboratory tests revealed the following: white blood cell count of $3.6 \times 10^{9} / \mathrm{L}$, red blood cell count of $1.54 \times 10^{12} / \mathrm{L}$, platelet count of $82 \times 10^{9} / \mathrm{L}$, hemoglobin of $4.45 \mathrm{~g} / \mathrm{dL}$, and lactate dehydrogenase of $266 \mathrm{U} / \mathrm{L}$. Due to pancytopenia, the patient was referred to the department of hematology before the excision. Peripheral blood smear showed 50\% neutrophils, 40\% lymphocytes, 8\% monocytes, and 2\% atypical cells. An excisional biopsy of skin lesions and a bone marrow biopsy (BMB) were performed. The BMB revealed monoblastic cell infiltration (40\%) and immunohistochemical stains were positive with CD34 and myeloperoxidase (Figures 2A-2D). CD13, CD34, CD117, CD4, CD33, myeloperoxidase, CD38, and CD11c were detected in the blastic cells, which 


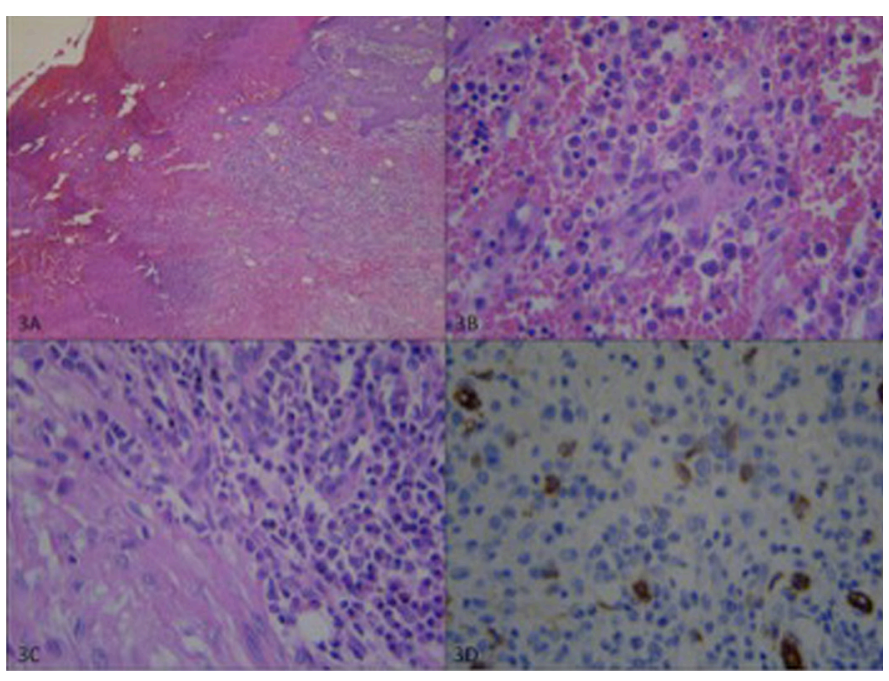

Figure 3. (A) Ulceration and pseudo-epitheliomatous hyperplasia in the epidermis, and inflammatory infiltration with capillary vessel proliferation under the epidermis (H\&E, 40x). (B, C) Occasional blastic cells with folded nuclei that show monoblastic morphology similar to the bone marrow and plasma cells with thin-walled capillaries (H\&E, 400x). (D) CD34 staining showing positivity in the endothelial cells intensely and scattered blasts (400x).

formed $31.4 \%$ of the population, by flow cytometry. The results were compatible with monoblastic leukemia and no genetic abnormalities were found. Histopathologically reactive lymphoplasmacytic infiltration in the dermis, including occasional blastic cells with morphologic features similar to the BMB findings like folded nuclei (Figures 3A-3D), was detected and diagnosed as granulocytic sarcoma (GS). However, the patient refused chemotherapy with azacitidine. Since cutaneous involvement of GS is rare and indicates poor prognosis, GS should be remembered in the differential diagnosis of suddenly emerging nodules and pustules $[1,2]$.

Keywords: Granulocytic sarcoma, Acute monoblastic leukemia, CD34, Myeloperoxidase

Anahtar Sözcükler: Granülositik sarkom, Akut monoblastik lösemi, CD34, Miyeloperoksidaz

Conflict of Interest: The authors of this paper have no conflicts of interest, including specific financial interests, relationships, and/or affiliations relevant to the subject matter or materials included.

\section{References}

1. Yilmaz AF, Saydam G, Sahin F, Baran Y. Granulocytic sarcoma: a systematic review. Am J Blood Res 2013;3:265-270.

2. Hurley MY, Ghahramani GK, Frisch $S$, Armbrecht ES, Lind AC, Nguyen $\Pi$, Hassan A, Kreisel FH, Frater JL. Cutaneous myeloid sarcoma: natural history and biology of an uncommon manifestation of acute myeloid leukemia. Acta Derm Venereol 2013;93:319-324. 